\title{
Groundwater flow pattern and water level fluctuation in western parts of Chitwan valley
}

\author{
*Sushmita Bhandari', Kabita Karki ${ }^{1}$, Surendra Maharjan ${ }^{2}$ and Suresh Das Shrestha ${ }^{3}$ \\ ${ }^{1}$ Department of Mines and Geology, Nepal \\ ${ }^{2}$ Ground water Resources Development Board (GWRDB), Branch officer Birgunj \\ ${ }^{3}$ Central Department of Geology, Tribhuvan University, Kirtipur, Kathmandu, Nepal \\ (Email:sushgeo12@gmail.com)
}

\begin{abstract}
Study of flow pattern and water level fluctuation in the western part of the Chitwan Valley was carried out in the area of 274.48 $\mathrm{km}^{2}$. The study area consists of alluvial deposits of the Narayani and the Rapti River of Pleistocene to Recent age. Aquifers in the study area are unconfined and semi confined to confined types. Based on the static water level, Jagatpur, Sukranagar and Gunjanagar are deep tube well zone and Shivanagar, Parbatipur, Patihani, Gitanagar are shallow tube well zone. The western half area discharges groundwater to the Narayani River and southern half discharges to the Rapti River rather than getting recharged throughout the year. Average water level fluctuation is $2.34 \mathrm{~m}$ with high fluctuation of $4.88 \mathrm{~m}$ at Sukranagar and low $0.49 \mathrm{~m}$ at Dibyanagar VDC. This fluctuation is directly related to rainfall.
\end{abstract}

Keywords: Hydrogeology, groundwater, flow pattern, Water level fluctuation, Chitwan,

Paper Received: 20 April 2015

Paper Accepted: 06 November 2015

\section{INTRODUCTION}

The hydrogeological study of the western parts of the Chitwan valley was carried out to study the groundwater flow pattern and water level fluctuation of the study area. The Chitwan valley lies approximately $146 \mathrm{~km}$ southwest from the Kathmandu, the capital city of the country. The study area covers the western part of the Chitwan District between longitudes $84^{\circ} 09^{\prime} 32^{\prime \prime}$ to $84^{\circ} 26^{\prime} 31^{\prime \prime}$ East and latitudes $27^{\circ} 32^{\prime} 50^{\prime \prime}$ to $27^{\circ} 42^{\prime} 10^{\prime \prime}$ North (Fig. 1). It is $10-12 \mathrm{~km}$ from the Narayanghat Bazar. The Narayani and the Rapti rivers are the major river systems of the area (Fig. 2). According to Iwata and Nakata (1982), the present study area lies in lower terrace. According to Acharya (2001), it lies in the Narayanghat Formation. The study area covers $274.48 \mathrm{~km}^{2}$ area and the population is 115,739 . The study area covers the part of the Topographical map of the Chitwan, sheet No 2784 06A, 2784 06B, 2784 06C, 2784 06D.

Geologically, Chitwan is a dun valley, trending NNW-SSE direction formed within the Sub-Himalaya of Nepal Himalaya. The Siwalik Range borders the Chitwan (Rapti) valley in the south, which consists of conglomerates of the Upper Siwaliks in the east while the Lower Siwaliks predominate in the west (Hagen 1969). In north, the Middle Siwaliks and the Lesser Himalayan Succession borders the valley. The Chitwan Dun Valley is composed of Pleistocene deposits consisting predominately of boulders, gravels and sands, which make good aquifers. Hence, it is potential for groundwater.

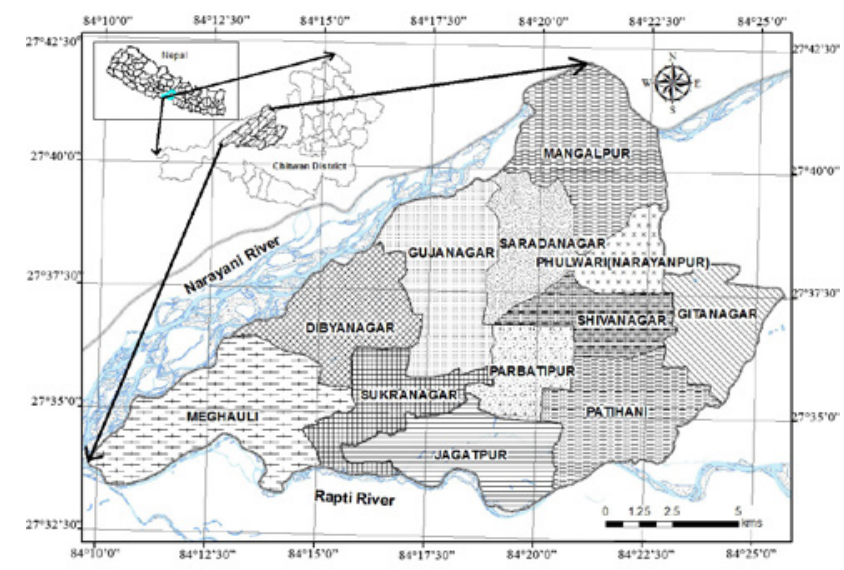

Fig.1: Location map of study area.

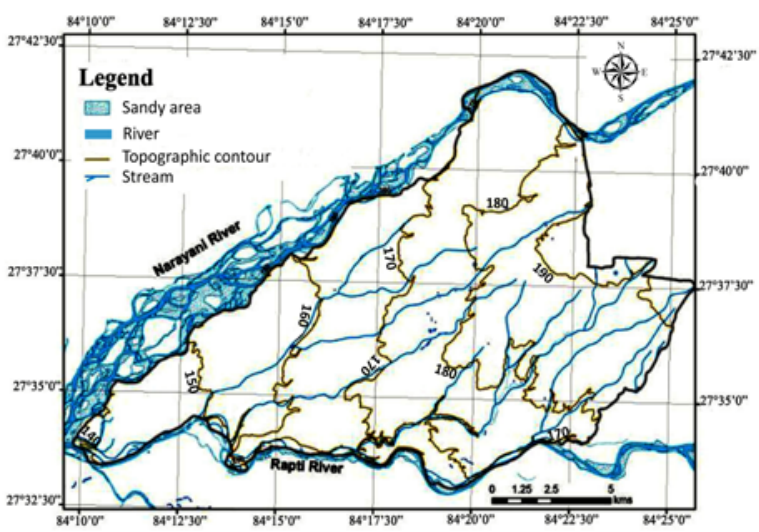

Fig. 2: Drainage map of study area. 


\section{METHODOLOGY}

This study was based mainly on the field study, and partly on the previous works. After the desk study, the field work was carried out in the 12 VDCs of the Western Chitwan and parts of the Bharatpur Sub Metropolitan City. Three field visits for data collection were carried out in April and May 2012 for three weeks, October 2012 for two weeks and in April 2013 for four days. During the field works, well sampling, well inventory and interaction with locals were done and lithological, hydrogeological, agricultural and socioeconomic data were collected. Well inventory included well depth, well diameter, static water level, screen depth, discharge, aquifer material, lithologs and primary use of well. From the well inventory data, groundwater flow pattern and water level fluctuation were determined. For this, the data collected were documented, processed, analyzed and interpreted by using Microsoft Excel 2007, Macromedia Freehand MXa and ArcGIS 9.3.

\section{RESULTS AND DISCUSSION}

The sediments in the area comprise terrace deposits of the Narayani and the Rapti River. Lithological data shows that the whole study area consists of sand, gravels and boulders while clay layers were encountered at Sukranagar and Jagatpur area. Clayey sand and gravels are present at Gunjanagar and Rampur area. Aquifers present are unconfined, semi confined to confined types.

\section{Well inventory and well depth map}

All the wells (dug wells, shallow tube wells and deep tube wells) included in the study are shown in a well inventory map (Fig. 3). This map gives the present well distribution pattern in the study area. It shows that there is high density of well number in the study area. From well inventory data, the well depth map is prepared. This map shows the general depth of well in specific area. Well depth pattern indicates the depth of aquifers in that area. According to the depth of wells in the area, six well depth zones are identified (Fig. 3).

1. $0-15 \mathrm{~m}$ : This zone is found near the Narayani and Rapti river side. It is distributed in Meghauli, Dibyanagar, Gunjanagar, Gitanagar and some area of Shivanagar, Parbatipur and Patihani VDCs as shown in map.

2. $\quad 15-30 \mathrm{~m}$ : This zone is found in the periphery of zone 1 in Meghauli, Dibyanagar, Sharadanagar, Narayanpur and Patihani VDCs.

3. 30-50 m: This zone occurred at the confluence area of the Narayani and Rapti River, at Jagatpur, Sukranagar and Sharadanagar VDCs.

4. 50-75 m: This zone is found at Jagatpur, Sukranagar and Mangalpur VDCs.

5. 75-100 m: This zone is found at Jagatpur and Mangalpur VDCs.

6. $>100 \mathrm{~m}$ : This zone lies at central part of Jagatpur VDC.

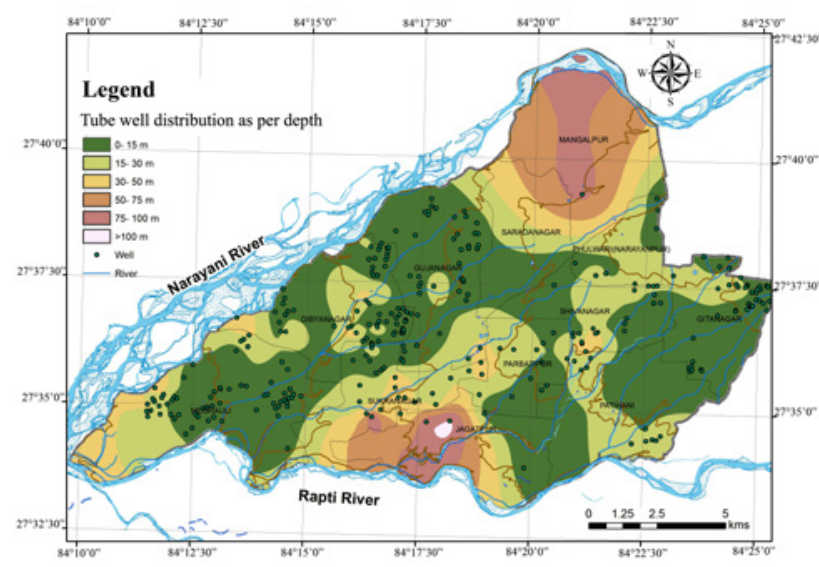

Fig. 3: Well inventory and well depth map of the study area.

\section{Static Water level}

Static water level was measured in the dug wells of the study area at the time of pre-monsoon (April and May) and post-monsoon (October), based on which hydrogeological maps are prepared (Fig. 4, 5, 6, and 7).

\section{Pre-Monsoon water level (Bgl)}

The pre-monsoon water level map shows that the static water level varies from $1.52 \mathrm{~m}$ at Shivanagar to $12.20 \mathrm{~m}$ below ground level at Dibyanagar. The water level was shallow at Shivanagar, Parbatipur, Patihani areas and deep at certain parts of Jagatpur, Sukranagar and Dibyanagar VDCs (Fig. 4).

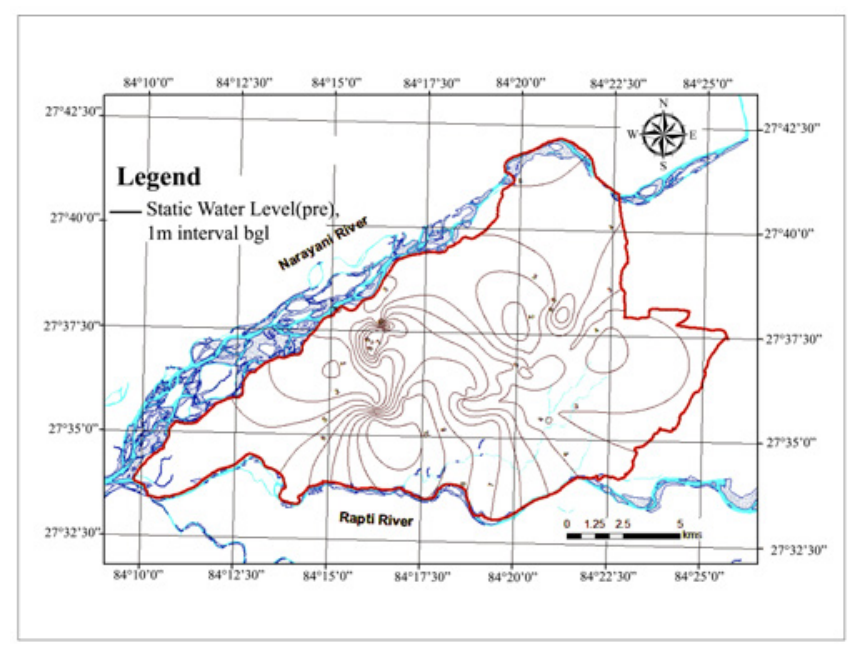

Fig. 4: Pre-monsoon water level map (bgl).

\section{Post-Monsoon water level (bgl)}

The post monsoon water level map shows that the static water level varies from $0.46 \mathrm{~m}$ below ground level at Parbatipur to more than $7.62 \mathrm{~m}$ below ground level at Dibyanagar. The water level was shallow at Shivanagar, Parbatipur, Patihani and Gitanagar VDCs and deep at Dibyanagar, Jagatpur and Sukranagar VDC (Fig. 5). 


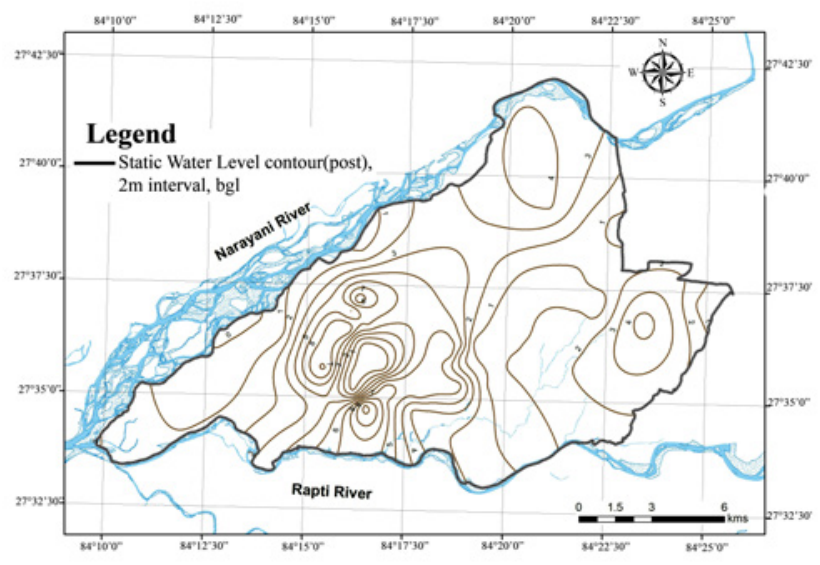

Fig. 5: Post-monsoon water level map (bgl).

\section{Flow pattern}

Equipotential maps of pre-monsoon and post-monsoon period, prepared from mean above sea level water level data, show the flow pattern (Fig. 6 and 7). They show that the flow of groundwater in the study area is towards the Narayani and the Rapti River. At Mangalpur water flows from east to west and discharge at the Narayani River. From Gitanagar and Patihani water flows to south-west and discharges at Rapti River. From Shivanagar, Parbatipur and Jagatpur water reaches to the Rapti River. Groundwater from Gunjanagar, Dibyanagar and Meghauli flows to the Narayani River. About 30\% of total study area discharges water to the Rapti River and 70\% area discharges water to the Narayani River.

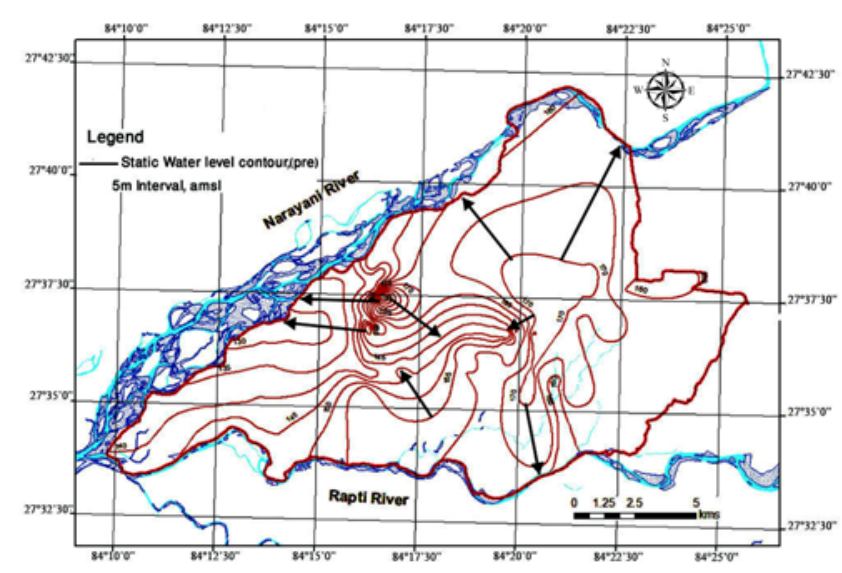

Fig. 6: Pre-monsoon water level map (amsl) and flow pattern.

\section{Water level fluctuation}

The well inventory data of pre-monsoon and postmonsoon (Fig. 8) show the average water level fluctuation is $2.34 \mathrm{~m}$ ranging from $0.49 \mathrm{~m}$ at Dibyanagar to $4.88 \mathrm{~m}$ at Sukranagar (Fig. 9).

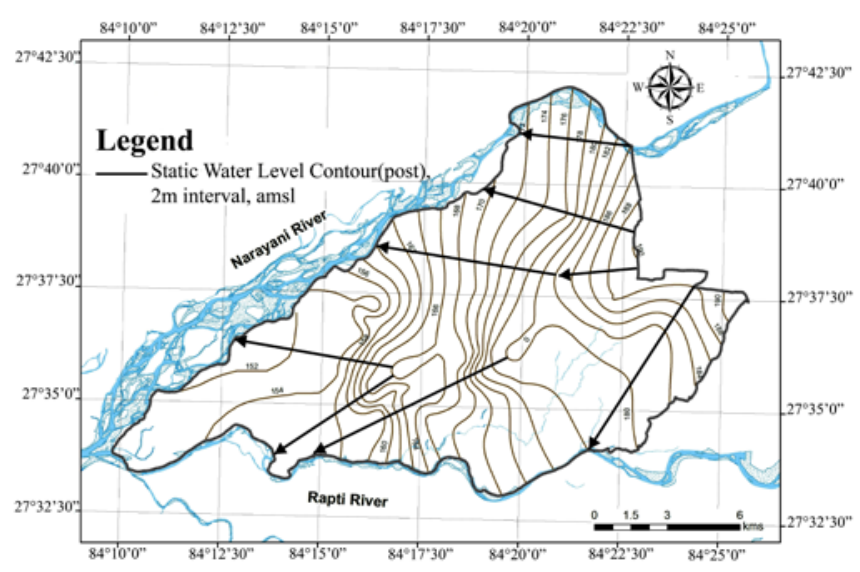

Fig. 7: Post-monsoon water level map (amsl) and flow pattern.

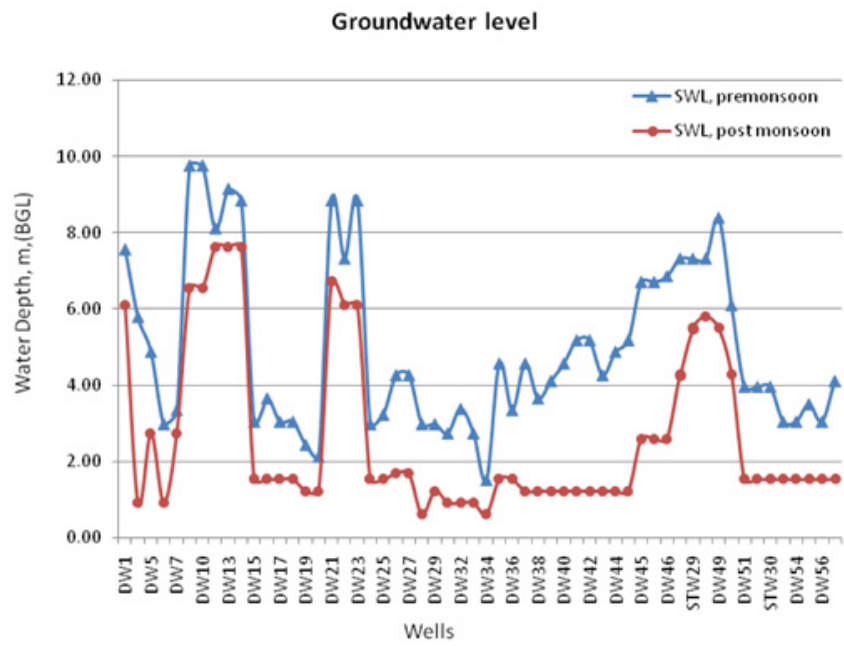

Fig. 8: Static water level in study area.

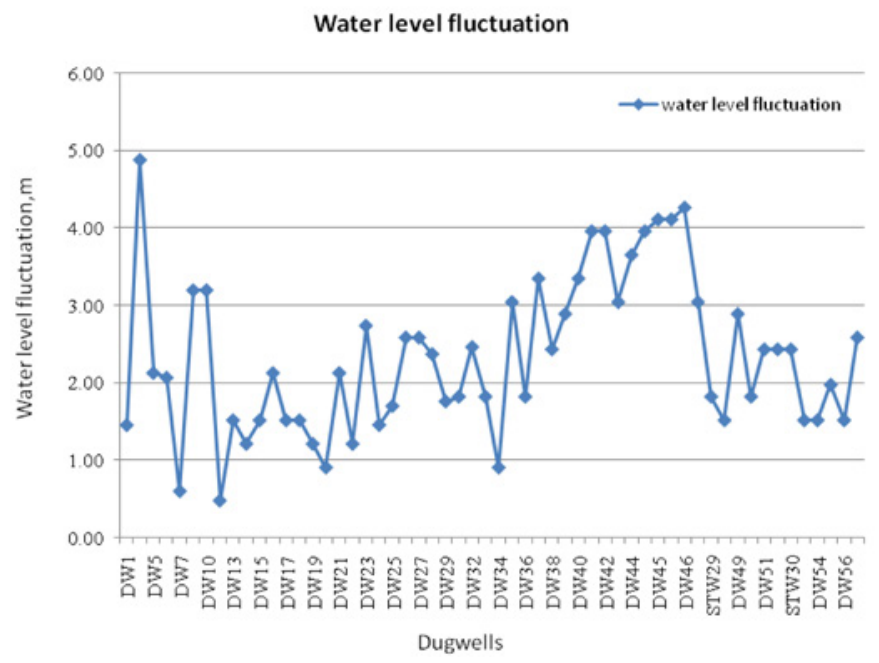

Fig. 9: Static water level fluctuation in study area. 


\section{CONCLUSIONS}

The sediments in the area comprise terrace deposits of the Narayani and Rapti River. The aquifers are unconfined, semi confined to confined types. On the basis of static water level and distribution of installed tube wells at Jagatpur, Sukranagar and Gunjanagar show the deep tube well zone and those at Shivanagar, Parbatipur, Patihani, Gitanagar show the shallow tube well zone.

Groundwater flow lines show that the groundwater flow is towards the Narayani and the Rapti River. The western half area discharges to the Narayani River and southern half discharges to the Rapti River. Groundwater is discharged to the rivers rather than being recharged, it is mainly due to low elevation of river line than of groundwater flow line. Nevertheless, condition on the periphery of river varies according to season. The water level is deeper in Dibyanagar, Gunjanagar, Sukranagar and Jagatpur VDCs and shallow at Shivanagar, Patihani, Gitanagar and Parbatipur VDCs. Water level fluctuation is high, $4.88 \mathrm{~m}$ at Sukranagar while it is low $0.49 \mathrm{~m}$ at Dibyanagar VDC. Average static water level fluctuation of the area is $2.34 \mathrm{~m}$.

\section{ACKNOWLEDGEMENTS}

The authors are grateful to Mr. Rajendra Neupane, Senior Divisional Hyrogeologist of Ground water Resources Development Board (GWRDB), Khaireni, Chitwan, Mr. Anil Khatri, Hydrogeologist of Ground Water Irrigation Project (GWIP), Chitwan and all our colleagues for guiding us and helping us throughout the study.

\section{REFERENCES}

Acharya, S.L., 2001, Hydrogeological study in Bharatpur area of the Chitwan Dun Valley, central Nepal. M. Sc. Dissertation submitted to the Central Department of Geology, T.U. (Unpublished).

Hagen, T., 1969, Report on geological survey of Nepal, v. 1: preliminary reconnaissance. Denk schrifter der Schwei zerischen Naturrforschenden Gesellschaft, 86 (I), Jurich, $185 \mathrm{p}$.

Iwata, S. and Nakata, T., 1985, River terraces and crustal movement in and around Narayanghat, central Nepal. Jour. Nepal Geol. Soc, v. 3, pp. 30-40. 